\title{
Nutritional strategies for minimizing phosphorus pollution from the livestock industry
}

Book or Report Section

Proof version

Ray, P. P. and Knowlton, K. F. (2015) Nutritional strategies for minimizing phosphorus pollution from the livestock industry. In: Malik, P. K., Bhatta, R., Takahashi, J., Kohn, R. and Prasad, C. S. (eds.) Livestock Production and Climage Change. CABI Climate Change Series (6). CAB International, Wallingford, pp. 74-89. ISBN 9781780644325 doi: https://doi.org/10.1079/9781780644325.0074 Available at http://centaur.reading.ac.uk/66157/

It is advisable to refer to the publisher's version if you intend to cite from the work. See Guidance on citing.

To link to this article DOI: http://dx.doi.org/10.1079/9781780644325.0074

Publisher: $C A B$ International 
including copyright law. Copyright and IPR is retained by the creators or other copyright holders. Terms and conditions for use of this material are defined in the End User Agreement.

\section{www.reading.ac.uk/centaur}

\section{CentAUR}

Central Archive at the University of Reading

Reading's research outputs online 


\title{
(1) F Nutritional Strategies for Dinimizing Phosphorus Pollution from the Livestock Industry
}

\author{
P.P. Ray and K.F. Knowlton \\ Virginia Tech, Blacksburg, USA
}

\begin{abstract}
Livestock manure traditionally has been considered and used as a valuable resource by farmers to improve crop production. Livestock manure is rich in nutrients (nitrogen $(\mathrm{N})$ and phosphorus $(\mathrm{P})$ ) and thus has been land applied to enrich soils. But land application of manure nutrients in excess of crop requirements can lead to saturated soil and loss of nutrients to surface water via runoff. Environmental concerns with $\mathrm{P}$ from animal agriculture are significant because livestock manure has always been land applied to meet crops' $\mathrm{N}$ requirement, resulting in $\mathrm{P}$ application in excess of crops' $\mathrm{P}$ requirement. The problem is aggravated with the intensification of livestock production, and now animal agriculture has been identified as a primary source of water quality impairment in many regions. But intensification and continuous advancement of livestock production is required to meet the increasing demand of food supply to feed a growing global population. Therefore, management strategies are needed that will improve livestock production while supporting the environmental and social pillars of sustainability. Nutritional strategies are economically and environmentally efficient tools to reduce $\mathrm{P}$ excretion by livestock. This chapter discusses nutritional strategies including precision feeding, phase feeding and approaches to improve feed $\mathrm{P}$ availability.
\end{abstract}

\subsection{Introduction}

Intensification of livestock production in recent decades has resulted in challenges with appropriate manure utilization/ disposal. Manure is rich in phosphorus (P) because the $\mathrm{P}$ utilization efficiency of livestock is less than $50 \%$. Manure is usually land applied as fertilizer at a rate to meet crops' nitrogen $(\mathrm{N})$ requirement; this results in soil $\mathrm{P}$ saturation. Accumulated $\mathrm{P}$ in soil can reach water bodies via runoff and cause eutrophication, impairing aquatic ecosystems.

If intensification of livestock and advancement of livestock production continues, perpetual impairment of water quality is expected. But continuous improvement in livestock production is required to maintain the global economy and to meet the increasing demand of food supply. Global demand for animal protein is increasing, and this trend is expected to continue as the global population is estimated to reach 9 billion by 2050 . Intensification of livestock production is one of the options to maintain global food security, but a sole focus on intensification threatens the sustainability of the livestock industry by widening the gap between industry practices and societal perceptions and expectations (von Keyserlingk et al., 2013). Therefore, approaches are needed that increase the efficiency of animal protein production while supporting the environ-

*E-mail: drray@vt.edu 
mental and social pillars of sustainability. Nutritional strategies to reduce nutrient excretion meet this criterion.

\subsection{Livestock in P Pollution}

Livestock production in the USA has evolved into an intensive production system, with the vast majority of animal products originating from animal feeding operations (AFOs, defined as farms that include confinement for 45 days or more in a year). In the span of 15 years from 1982 to 1997, the number of AFOs increased by $10 \%$ (USDA, 2001). A similar trend was observed in manure production as AFO-generated manure approximately quadrupled from 133 million tonnes (Mt) in 1997 to $>500 \mathrm{Mt}$ in 2003 (USEPA, 1998, 2003). The largest AFOs are defined as concentrated animal feeding operations (CAFOs). CAFOs account for a small portion of livestock farms but accounted for half of manure $\mathrm{P}$ produced by all livestock farms in 1997 (up from 27\% in 1982; Kellogg et al., 2000).

Manure is a rich source of nutrients ( $N$ and $\mathrm{P}$ ) and is used as fertilizer to enhance crop production. Spatial intensification of livestock production creates problems, as the amount of manure produced per year overwhelms the assimilative capacity of cropland. Manure has traditionally been land applied to meet crops' $\mathrm{N}$ requirements, but because manure $\mathrm{N}$ and $\mathrm{P}$ are in imbalance relative to crop needs, this practice leads to accumulation of soil P. A summary of US soil tests indicates that soil from areas of intensive animal agriculture had excessive $P$. In 1996, the majority of soil tested by several soil-testing laboratories in the north-east was categorized as high or very high in soil test P (Sharpley, 1999).

Once soil is saturated with $\mathrm{P}$, it can reach surface water via runoff, increasing the risk of eutrophication, especially in fresh water (Sharpley and Tunney, 2000). A series of whole-lake experiments confirmed that $\mathrm{P}$ was the limiting nutrient for algal bloom in fresh water (Schindler, 1977). In the USA, an estimated $20 \%$ of agricultural impairment of water quality is from CAFOs, and more than $50 \%$ of the agricultural impairment for lakes and estuaries is by nutrients (USEPA, 1998). The source of nutrients contributing to water pollution varies regionally, and therefore a manure distribution problem may be local, regional, national or international. The semi-arid climate in the central and western regions of the USA, for instance, makes manure disposal less problematic as the risk of $\mathrm{P}$ runoff to surface water is less due to limited rainfall and the distant location of water bodies from farms (USEPA, 2012). The opposite scenario is observed in the Chesapeake Bay Watershed area, with its dense livestock population. In this region, manure contributes $27 \%$ of annual P load to Chesapeake Bay (Kleinman et al., 2012).

The $\mathrm{P}$ imbalance resulting from the land application of manure in excess of crop $\mathrm{P}$ needs is a global problem. In $62 \%$ of the global cropland area with surplus $P$, manure $\mathrm{P}$ application was in excess of crops' $\mathrm{P}$ use (MacDonald et al., 2011). The authors estimated that global recoverable manure $\mathrm{P}$ was $10 \mathrm{Mt}$ in 2000 . As is true regionally and nationally, global $\mathrm{P}$ surpluses result from dense livestock population in areas with inadequate cropland to assimilate manure $\mathrm{P}$ (Jongbloed and Lenis, 1998; Shigaki et al., 2006; Pathak et al., 2010; Wang et al., 2011). The association of $\mathrm{P}$ surpluses with intensified livestock population is not limited to one species; dairy, beef, swine and poultry production have all been identified as major contributors of $\mathrm{P}$ to eutrophic water bodies (Gaskin et al., 2001; Pote et al., 2003; Nelson and Mikkelsen, 2005; James et al., 2007; Fisher et al., 2009; Chebud et al., 2011).

At the county level, surplus manure $\mathrm{P}$ is more common than surplus manure N. In 1997, 155 counties in the USA had surplus manure $\mathrm{N}$ from CAFOs as compared to 337 counties with excess manure P (USDA, 2001). Therefore, limiting manure application to the $\mathrm{P}$ needs of crops (P-based nutrient management) is one way to reduce soil $\mathrm{P}$ accumulation and $\mathrm{P}$ runoff to surface water. Shifting manure application limits from $\mathrm{N}$ to $\mathrm{P}$ means increased acreage 
required for manure spreading, greater cost of manure application and an increase in the number of farms that need alternative ways to dispose of manure. All of these have significant economic impacts on the livestock sector.

\subsection{Assessment of Requirement and Overfeeding}

Increased awareness of the problem of $\mathrm{P}$ accumulation on livestock farms and the impacts of P-based nutrient management regulations led to an effort to develop and implement nutritional strategies to minimize $\mathrm{P}$ excretion without impairing production (VandeHaar and St-Pierre, 2006). $P$ is one of the macrominerals required for almost all living organisms with critical physiological functions including bone accretion, energy metabolism, rumen microbial growth (in ruminants), cell membrane structure, transport of fatty acids and nucleic acid structure. More than $80 \%$ of the total body $\mathrm{P}$ is in bone, and bone plays a role in regulating blood $\mathrm{P}$ by resorption (Ternouth, 1990). Therefore, bone accretion or replenishment of $\mathrm{P}$ in depleted bone is critical to maintain animal performance and production. As $\mathrm{P}$ is not synthesized in the body, $\mathrm{P}$ must be provided via dietary sources, but supplementation of $\mathrm{P}$ in excess of requirement and storage capacity results in excretion of $\mathrm{P}$ via faeces and urine or excreta (Knowlton et al., 2004). Therefore, precise assessment of dietary $\mathrm{P}$ requirement is critical from both nutritional and environmental perspectives.

\subsubsection{Dairy cattle}

The assessment of the $\mathrm{P}$ requirement of lactating cows has always been a matter of confusion, with variation within a feeding standard or between feeding standards used in different countries (Tamminga, 1992). The difficulty in assessing $\mathrm{P}$ requirements precisely is because of variation in factors that influence the $\mathrm{P}$ requirement, (e.g. physiological stage of production, dietary nutrient availability and the approach of calculating the requirement). In the USA, the National Research Council (NRC) uses the data from relevant animal experiments to calculate dietary $\mathrm{P}$ requirements. The current NRC recommended dietary P supply for lactating cows accounts for the requirement of absorbed $\mathrm{P}$ for milk production, maintenance, growth and reproduction (NRC, 2001). The resulting absorbed $\mathrm{P}$ requirement is divided by the estimated availability of feed $\mathrm{P}$ to calculate dietary $\mathrm{P}$ supply required to maintain production and performance. The requirement of total $\mathrm{P}$ as grams of total absorbed $\mathrm{P}$ and as a per cent of dietary dry matter (DM) is presented in Table 5.1. It is important to note that even though total absorbed $\mathrm{P}$ requirement ( $\mathrm{g}$ day ${ }^{-}$ $\left.{ }^{1}\right)$ does not change for a particular stage of production, dietary $\mathrm{P}$ requirement (\% of dietary DM) changes if DM intake (DMI) or feed ingredient changes.

The dietary $\mathrm{P}$ requirement of lactating cows for a specific age and stage of production is lower in current NRC recommendations (NRC, 2001) than it was in previous NRC recommendations (NRC, 1989), and the NRC recommended higher dietary P in 1989

Table 5.1. P requirement for Holstein lactating cows $(600 \mathrm{~kg}$ body weight; milk yield: $40 \mathrm{~kg} \mathrm{day}^{-1}$ ) at different dry matter intake (DMI). ${ }^{\mathrm{a}}$

\begin{tabular}{ccc}
\hline $\begin{array}{c}\text { DMI } \\
\left(\mathrm{kg} \mathrm{day}^{-1}\right)\end{array}$ & $\begin{array}{c}\text { Absorbed } \mathrm{P} \text { requirement } \\
\left(\mathrm{g} \mathrm{day}^{-1}\right)\end{array}$ & $\begin{array}{c}\text { Dietary } \mathrm{P} \text { requirement } \\
(\text { per cent of dietary DM })\end{array}$ \\
\hline 21.8 & 58 & 0.41 \\
23.2 & 59 & 0.38 \\
23.9 & 60 & 0.38 \\
25.3 & 61 & 0.36 \\
\hline
\end{tabular}

Note: aNRC (2001) predicted P requirement adapted from Knowlton et al. (2004). 
than it did in 1978. This discrepancy was due primarily to the change in assumed $\mathrm{P}$ availability. Dietary $\mathrm{P}$ availability in ruminants is variable and difficult to measure, and thus contributes to imprecise assessment of $\mathrm{P}$ requirement (Park et al., 1999; Bravo et al., 2002, 2003; Kincaid et al., 2005; Mjoun et al., 2008; Wang et al., 2008; Martín-Tereso et al., 2009). This usually leads to inclusion of safety margins, and subsequently to excess dietary $\mathrm{P}$.

In the 1978 and 1989 NRC recommendations, a single value was used for $\mathrm{P}$ availability (55 and $50 \%$, respectively). In current NRC recommendations (2001), assumed $\mathrm{P}$ availability varies by type of feed (64, 70 and $>75 \%$ for forages, concentrates and minerals, respectively). This attempt to account for variability in the availability of $\mathrm{P}$ from different sources has improved the precision of dietary $\mathrm{P}$ requirement calculation, but variation in $\mathrm{P}$ availability within a type of feed (forage or concentrate) still contributes to uncertainty.

The dietary $\mathrm{P}$ requirement for mediumto high-producing cows is about 0.31$0.35 \%$; animals start showing deficiency symptoms when dietary $\mathrm{P}$ concentration is $<0.30 \%$ of dietary DM (Valk and Šebek, 1999; Wu et al., 2000; NRC, 2001; Wu et al., 2001). In 2001, a survey involving 98 dairy farms in the Chesapeake Bay Watershed indicated that $93 \%$ of the farms were overfeeding P (Dou et al., 2003). The situation has improved since then (Harrison et al., 2012). In a nationwide 2010 survey, just $8.5 \%$ of the respondents felt that the current NRC (2001) recommendation of P for dairy cows was too low, but $40 \%$ of the respondents indicated $\mathrm{P}$ overfeeding, for multiple reasons.

In addition to the uncertainty about dietary $\mathrm{P}$ requirement, other factors contributing to the overfeeding of $\mathrm{P}$ to dairy cows are: the perception that high dietary $\mathrm{P}$ will improve reproductive performance; variation in feed $\mathrm{P}$ concentrations; and the inclusion of high $\mathrm{P}$ and relatively inexpensive by-product feed ingredients. The notion that increasing dietary $\mathrm{P}$ will improve reproductive performance probably originates from the studies with range or beef cattle, as mentioned by Satter et al. (2002) and Knowlton et al. (2004) in their review of animal management strategies to reduce $P$ pollution. But in those studies, dietary $\mathrm{P}$ was much lower than the current recommendation (NRC, 2001).

Large variation in $\mathrm{P}$ concentration within a feed ingredient also contributes to $\mathrm{P}$ overfeeding in dairy cows. Satter et al. (2002) calculated within-feed ingredient variation in $\mathrm{P}$ concentration for the feedstuffs listed by the NRC (2001) and reported $\sim 15 \%$ coefficient of variation. Coefficient of variation for $\mathrm{P}$ concentration ranged from $20-26 \%$ and $14-36 \%$, respectively, in hay and silage samples analysed by the Northeast DHI Forage Laboratory during one 12-month period (Kertz, 1998). Coefficient of variation was lower for concentrates than for forages (3 versus 11\%) in 170 samples from nine regions in the USA (Jarrett et al., 2011). The degree of regional variation was higher than variation by feed type $(2-30 \%$ versus $3-11 \%)$. Another reason why dietary $\mathrm{P}$ in dairy cattle diets often exceeds requirements is the increasing popularity and inclusion of nutrient-rich, high $\mathrm{P}$ by-products to the dairy cattle diet. Most of these by-products are good sources of protein, but also very high in $\mathrm{P}$ content.

\subsubsection{Beef}

As in dairy, the $\mathrm{P}$ requirement for beef cattle is calculated using a factorial method by dividing the sum of $\mathrm{P}$ requirements (for maintenance, growth, pregnancy and lactation) by the absorption coefficient of $\mathrm{P}$. The current beef NRC (1996) recommendation uses a fixed absorption coefficient of 0.68 to calculate dietary $\mathrm{P}$ requirement. As per current NRC calculations (1996), the P requirement of feedlot steers weighing between 200 and $450 \mathrm{~kg}$ is approximately 15-26 $\mathrm{g} \mathrm{day}^{-1}$, equivalent to $0.20-0.30 \%$ dietary P (of dietary DM) when feed intake is 10-12 kg day ${ }^{-1}$ (Table 5.2).

There are several reports that the NRC (1996) recommended dietary P supply for feedlot cattle is higher than necessary. This 
Table 5.2. $P$ requirement for growing and finishing Angus cattle at different body weight and average daily gain. (From NRC, 1996.)

\begin{tabular}{|c|c|c|c|c|c|c|}
\hline \multirow{3}{*}{ Function } & \multicolumn{6}{|c|}{ Body weight $(\mathrm{kg})$} \\
\hline & 200 & 250 & 300 & 350 & 400 & 450 \\
\hline & \multicolumn{6}{|c|}{$P$ requirement $\left(g_{\text {day }}^{-1}\right)$} \\
\hline $\begin{array}{l}\text { Maintenance } \\
\text { Growth (ADG }{ }^{\mathrm{kg}} \text { day }^{-1} \text { ) }\end{array}$ & 5 & 6 & 7 & 8 & 10 & 11 \\
\hline 0.5 & 6 & 5 & 5 & 4 & 4 & 4 \\
\hline 1 & 11 & 10 & 9 & 8 & 8 & 7 \\
\hline 1.5 & 16 & 15 & 13 & 12 & 11 & 10 \\
\hline 2 & 21 & 19 & 18 & 16 & 14 & 13 \\
\hline 2.5 & 26 & 24 & 22 & 19 & 17 & 15 \\
\hline
\end{tabular}

Note: ${ }^{\mathrm{A} A D G}=$ average daily gain

is likely because the $\mathrm{P}$ requirement for gain and $\mathrm{P}$ availability in the 1996 NRC recommendations were calculated from data published 20-60 years ago (Ellenberger et al., 1950; Tillman et al., 1959; Martz et al., 1990). The $P$ requirement of yearling steers with an average daily gain (ADG) of $1.5 \mathrm{~kg}$ day $^{-1}$ was evaluated by feeding a range of dietary P from 0.14 to $0.34 \%$ of DM. These grain-fed finishing steers required $0.14 \%$ or less dietary $\mathrm{P}$, about $70 \%$ of the current (NRC, 1996) recommendation (Erickson et al., 1999). In a similar experiment with feedlot calves, $0.16 \% \mathrm{P}$ was found to be adequate (Erickson et al., 2002). Geisert et al. (2010) confirmed the results of Erickson et al. (1999) and concluded that the $\mathrm{P}$ requirement of finishing feedlot cattle was between 0.10 and $0.17 \%$ of dietary DM, much lower than the NRC (1996) recommendation. These results suggested that NRC (1996) overestimated the P requirement of grain-fed feedlot cattle and supplementation of $\mathrm{P}$ was not necessary. Similarly, Brokman et al. (2008) reported that P supplementation was not necessary for Holstein steers raised on pasture, given that high-quality grass was provided.

\subsubsection{Swine}

The assessment of $\mathrm{P}$ requirement for swine was originally with an empirical approach (NRC, 1979). Several studies were conducted to estimate the $\mathrm{P}$ requirement of pigs at different physiological stages, and until the late 1980s, the P requirement of swine was reported as total P (NRC, 1979; Combs et al., 1991). There has always been a discrepancy in $\mathrm{P}$ requirements between individual studies and NRC recommendations, largely because of the variation in $\mathrm{P}$ availability in different feed ingredients. The widespread adoption of exogenous phytase in swine diets has allowed reductions in dietary (and hence manure) P (Selle and Ravindran, 2008), but also contributes to the variation and uncertainty of feed $\mathrm{P}$ availability. The impact of phytase feeding is discussed in more detail later in this chapter. Thus, estimates of $\mathrm{P}$ requirements for swine continue to vary between studies or NRC standards (NRC, 1998; Hastad et al., 2004).

A first step toward an improved assessment system to estimate the $P$ requirements of swine was the expression of $P$ requirement as available or digestible $P$ required in grams per day or per cent of diet (NRC, 1988; Ketaren et al., 1993; Hastad et al., 2004; Ruan et al., 2007). The data set limitations inherent to the empirical approach continued to constrain progress, because evolving production systems and changing genetics and nutrition of pigs were not accounted for. Only a limited number of studies were available to estimate empirical $\mathrm{P}$ requirement in growing-finishing pigs, and $60 \%$ of the studies were conducted 20 or more years ago.

For these reasons, direct assessment of $\mathrm{P}$ requirement from empirical results was 
replaced by derivation of $\mathrm{P}$ requirements using nutrient-based models in the current NRC revision (NRC, 2012). In the current NRC recommendations (NRC, 2012), standardized total tract digestible (STTD) P is estimated, by refining or adding several model parameters such as whole-body $\mathrm{P}$ retention, endogenous $\mathrm{P}$ loss, marginal efficiency of using STTD-P intake and P requirement for maximal growth as a proportion of $\mathrm{P}$ required for maximum wholebody $\mathrm{P}$ retention. With this refinement, model-derived requirements of STTD-P for all stages of pigs were lower than estimated in the previous NRC recommendations (NRC, 1998; Table 5.3).

In swine, as in other species, uncertainty about $\mathrm{P}$ requirement and the difference in $\mathrm{P}$ requirements between individual pig and a group of pigs contributes to overfeeding of $\mathrm{P}$. Overfeeding of P to pigs at $110-150 \%$ of the NRC (1998) recommendation for swine from the 1980s to the mid-1990s was revealed in a survey by Kornegay and Verstegen (2001). Environmental loading of $\mathrm{P}$ via faeces changes with production stage, as faecal $\mathrm{P}$ excretion (as a per cent of $\mathrm{P}$ intake) varies with age. The maximum contribution (up to $75 \%$ of total lifetime P excretion) is during the growing stage (Poulsen et al., 1999).

\subsubsection{Poultry}

As with dairy, beef and swine, the NRC publication is the centralized and recognized reference for nutrient requirements in poultry, but the most recent NRC recommendation for poultry (NRC, 1994) is almost 20 years old. Dietary requirements are reported as a concentration of nonphytate $\mathrm{P}(\mathrm{nPP})$. In the current NRC recommendations (NRC, 1994), dietary $\mathrm{P}$ recommendations for broilers, laying hens and turkeys are based on empirical research from 1952 to 1983,1949 to 1987 and 1954 to 1986 , respectively. Thus, recent studies have shown that the dietary concentration of $\mathrm{nPP}$ found to maintain the production and performance of broilers and laying hens is lower than that recommended by the NRC (NRC, 1994; Fig. 5.1). In contrast, although the published dietary $\mathrm{P}$ recommendation for turkeys (Fig. 5.1) are based on similarly old studies, they seem to match well reported results for actual $\mathrm{P}$ requirement of turkeys (Roberson, 2004).

In the early 1990s, there were few studies evaluating the $\mathrm{P}$ requirement of broilers, but most studies confirmed overestimation of $\mathrm{P}$ requirement for broilers by the NRC (NRC, 1994). The nPP requirement for broiler chicks (0-3 weeks of age) was 0.32 and $0.37-0.39 \%$ for optimum body weight (BW) and tibia ash, respectively (Waldroup et al., 2000). For the same response criteria, nPP requirement for broilers of age 3-6 weeks was 0.19 and $0.33 \%$, respectively (Yan et al., 2001).

To refine $\mathrm{P}$ feeding (and also reduce feed costs), the broiler industry is shifting from a three-phase feeding programme (as in most studies and the current NRC recommendations) to a four-phase feeding programme. This contributes to imprecise assessment of $\mathrm{P}$ requirement for broilers. The fourth stage is referred to as the withdrawal phase, and $\mathrm{P}$ requirements are less in this stage than in the finisher stage. Dhandu and Angel (2003) reported P requirements of 0.20 and $0.16 \%$ for finisher and withdrawal phases, respectively, as compared to $0.30 \%$ for the finisher phase recommended by NRC (1994).

Table 5.3. $P$ requirement for growing-finishing pigs. (Adopted from NRC, 2012.)

\begin{tabular}{|c|c|c|c|c|c|c|}
\hline & \multicolumn{6}{|c|}{ Body weight (kg) } \\
\hline & $20-50$ & & \multicolumn{2}{|l|}{$50-80$} & \multicolumn{2}{|c|}{$80-120$} \\
\hline & \multicolumn{6}{|c|}{ Year of NRC publication } \\
\hline & 1998 & 2012 & 1998 & 2012 & 1998 & 2012 \\
\hline STTD P, ${ }^{a}$ per cent of diet & 0.30 & 0.24 & 0.26 & 0.21 & 0.21 & 0.18 \\
\hline
\end{tabular}

Note: aSTTD P = standardized total tract digestible P. 


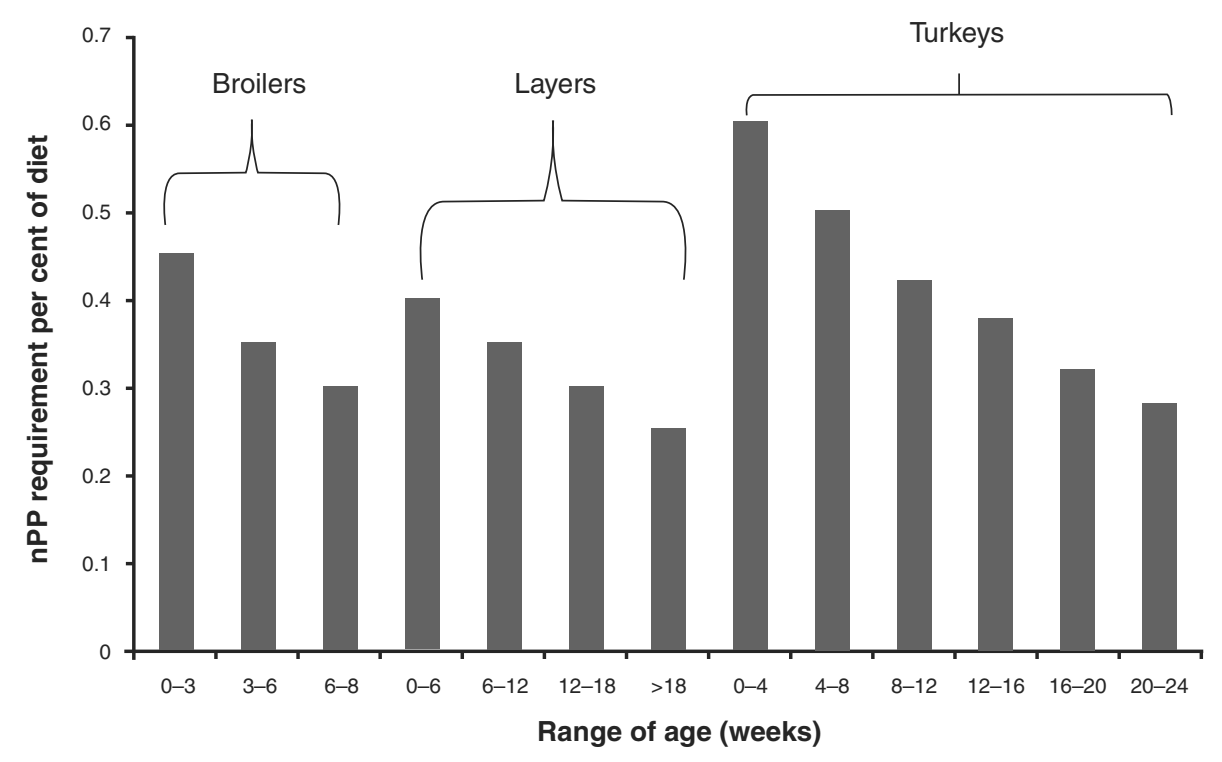

Fig. 5.1. Non-phytate phosphorus (nPP) requirements of broilers, layers and turkeys (NRC, 1994).

As with broilers, the $\mathrm{P}$ requirement of growing pullets is also overestimated by NRC (1994), as reported by Keshavarz (2000). Non-phytate P concentration required for optimum performance of pullets was $0.20,0.15$ and $0.10 \%$ at $0-6$, 6-12 and 12-18 weeks of age, respectively, as compared to $0.40,0.35$ and $0.30 \%$ recommended by NRC (1994).

As in other species, variation in $P$ content and bioavailability of $\mathrm{P}$ in feed partially explains overfeeding of $\mathrm{P}$ to poultry (the inclusion of a margin of safety; Huyghebaert et al., 1980; Waibel et al., 1984). For instance, the use of animal by-products as a protein source is common in the poultry industry, and $\mathrm{P}$ concentration varies not only between these ingredients but also within feed ingredients (coefficient of variation for $\mathrm{P}$ concentration in bone and meat meal from different sources: 9-17\%; Waldroup, 1999). Also, advances in genetics result in continual gains in nutrient utilization and growth efficiency in all species of poultry (Havenstein et al., 2003). These changes justify continuing investment in research on nutrient requirements.

\subsection{Nutritional Strategies for Minimizing Environmental Load of $\mathbf{P}$}

Nutritional strategies are more efficient than most other best management practices to reduce environmental loading of $\mathrm{P}$ contributed by livestock as they improve the economy of the livestock industry, reducing feed cost and reducing manure disposal costs, and thereby reducing the environmental burden of the food animal industry.

\subsubsection{Ruminants: dairy and beef cattle}

\section{Remove excess dietary $P$}

In ruminants, faecal $P$ excretion is correlated positively with $\mathrm{P}$ intake (Knowlton and Herbein, 2002; Geisert et al., 2010; Ray et al., 2013). In the field, overfeeding of $P$ to dairy and beef cattle is very common (Erickson et al., 1999; Dou et al., 2003; Arriaga et al., 2009). The perception that increasing dietary $\mathrm{P}$ will improve reproductive performance in dairy cows has persisted, but the literature data clearly indicate the opposite. For instance, no 
difference in the occurrence of reproductive problems was observed in Holstein cows fed dietary P close to the NRC (2001) recommendation and in excess of its recommendation (0.37 versus $0.57 \%$ of dietary DM) (Lopez et al., 2004). In another experiment, decreasing dietary $\mathrm{P}$ from $0.49 \%$ to $0.40 \%$ or $0.31 \%$ of dietary DM did not influence the reproductive performance of lactating cows negatively during a 306day trial, and $\mathrm{P}$ excretion $\left(\mathrm{g} \mathrm{day}^{-1}\right.$ ) decreased by $23 \%$ when dietary P decreased from 0.49 to $0.40 \%$ (Wu et al., 2000).

Similarly, dietary P does not affect milk production, except in severe deficiency. Reducing dietary $\mathrm{P}$ in early lactation Holstein cows did not affect milk yield and composition (Knowlton and Herbein, 2002), and total P excretion decreased by 20 and $57 \%$ when dietary $\mathrm{P}$ was reduced from 0.67 to $0.51 \%$ and from 0.51 to $0.34 \%$ of dietary DM, respectively. Similarly, Odongo et al. (2007) did not observe any negative effect of reducing dietary P from 0.42 to $0.35 \%$ (DM basis) on the production of lactating Holstein cows, but faecal P excretion decreased. Milk production was not affected in dairy cows fed $0.31 \%$ dietary P during the first two-thirds of lactation, but in the last one-third of lactation, cows fed these very low P diets yielded less milk as compared to those fed 0.40 or $0.49 \%$ dietary P (Wu et al., 2000). This indicated the lowest threshold of dietary $\mathrm{P}$ to maintain production in dairy cows. In current feeding systems, dairy cows are fed high-concentrate diets, often with high-P feed ingredients, and thus it is nearly impossible to formulate a dairy ration with $<0.33-0.35 \%$ P.

The impact of reducing overfeeding on $\mathrm{P}$ loading from livestock farms is dramatic. Kebreab et al. (2008) used a mechanistic modelling approach to simulate faecal $\mathrm{P}$ excretion by Ontario dairy cows. Reduction in dietary P from $0.42 \%$ to $0.35 \%$ reduced total $\mathrm{P}$ contribution from dairy farms by 1300 t year $^{-1}$.

As in the dairy industry, excess $P$ can be removed from beef cattle diets without impairing production and performance. Reduction in dietary $\mathrm{P}$ did not affect daily gain, feed efficiency, bone ash and rib bone breaking strength when steers were fed $0.14 \%$ dietary P (per cent of dietary DM) as compared to higher dietary concentrations (0.34, 0.29. 0.24 and $0.19 \%$ of dietary DM) (Erickson et al., 1999). Similarly, the combined results of two experiments with finishing beef cattle suggested that dietary $\mathrm{P}$ could be reduced to $0.17 \%$ of dietary DM without affecting daily gain, feed efficiency, carcass quality and phalanx ash (Geisert et al., 2010). This will result in a greater than $40 \%$ reduction in faecal $P$ excretion.

\section{Improving $P$ bioavailability}

A second strategy to reduce $\mathrm{P}$ excretion by all species of livestock is to improve the bioavailability of feed P, allowing further reductions in dietary $P$. Bioavailability of $P$ in feed ingredients depends primarily on the form of $\mathrm{P}$ in feed and the animal's capability to degrade organic forms of $\mathrm{P}$ into absorbable inorganic forms. Ruminants are blessed with the presence of microbial phytase in the rumen to degrade and utilize phytate $P$, the major form of P in grains (Yanke et al., 1998). Ruminal phytase activity can vary with type of feed and dietary phytate $\mathrm{P}$ concentration, and hence $\mathrm{P}$ bioavailability can vary even in ruminants (Godoy and Meschy, 2001). In addition, dietary phytate $\mathrm{P}$ degradation or $\mathrm{P}$ digestion varies with type of feed ingredient and feed processing (Park et al., 2000; Kincaid et al., 2005; Mjoun et al., 2008; Martín-Tereso et al., 2009). Therefore, the selection of feed ingredient is an important criterion in the effort to improve dietary P availability.

Supplementation of exogenous phytase has yielded great improvements in $\mathrm{P}$ availability in swine and poultry diets (see below), but the practice has less benefit in ruminant diets. Ruminal phytase activity leaves less opportunity for supplemented phytase to increase the release of inorganic $\mathrm{P}$ from phytate molecules. There are mixed reports about the advantage of supplementing the ruminant diet with exogenous phytase (Bravo et al., 2002; Kincaid et al., 2005; Knowlton et al., 2007). The results from these studies indicated that the advantage of exogenous phytase in 
improving $\mathrm{P}$ availability might be achieved only if ruminal phytate hydrolysis by endogenous phytase was somehow limited and dietary $\mathrm{P}$ was at or below the $\mathrm{P}$ requirement of the animal (Jarrett et al., 2014).

\subsubsection{Non-ruminants - swine and poultry}

\section{Remove excess dietary $P$}

As in all species, eliminating $\mathrm{P}$ overfeeding to pigs will reduce $\mathrm{P}$ excretion. Thirty-six finishing boars were fed 0.15, 0.20 and $0.30 \%$ dietary available P (Varley et al., 2010). Digestibility of DM, ash and fibre was not influenced by dietary $\mathrm{P}$, and faecal and urinary $\mathrm{P}$ output decreased with decreasing dietary P. Further, reductions in dietary $\mathrm{P}$ to below $0.20 \%$ resulted in decreased ADG, feed efficiency and bone ash. Therefore, there is no need to feed pigs over the NRC (1998) recommendation. Further research is needed to evaluate the effect of feeding $\mathrm{P}$ close to the current NRC (2012) recommendation on the performance and nutrient excretion by pigs.

As in cattle, faecal $\mathrm{P}$ excretion in poultry increases gradually as dietary $\mathrm{P}$ increases from deficient to the point that tibia ash content reaches maximum, and excretion increases sharply thereafter. Turkeys and broilers excreted $19-33 \%$ and $10-17 \%$ less total P when they were fed closer to their genus-specific $\mathrm{nPP}$ requirement (Maguire et al., 2004). Reducing dietary nPP concentration from 0.30 to 0.24 and to $0.15 \%$ resulted in a 19 and $30 \%$ increase in $P$ retention by white leghorn laying hens without compromising egg production and egg quality (Panda et al., 2005). Therefore, reduced overfeeding is a potential strategy to reduce $\mathrm{P}$ excretion by poultry.

\section{Multi-phase feeding}

The concept of phase feeding is based on the use of multiple diets to match the continuously changing nutrient requirements of growing pigs (or other species) as closely as possible, and phase feeding became popular in the swine industry during the 1990s to reduce nutrient excretion by pigs. With age, the BW of growing pigs increases and the STTD-P requirement $\left(\mathrm{g} \mathrm{day}^{-1}\right)$ also increases. But the needed dietary STTD-P concentration decreases due to increased feed intake with age. For example, the STTD-P requirement for pigs increases from $1.2 \mathrm{~g} \mathrm{day}^{-1}$ at $5-7 \mathrm{~kg}$ BW to $5.95 \mathrm{~kg} \mathrm{day}^{-1}$ at 100-135 kg BW, but the required dietary STTD-P concentration decreases from 0.45 to $0.21 \%$ (NRC, 2012).

Data on the effect of phase feeding on $\mathrm{P}$ excretion by pigs are scarce. When different feeding regimens (one-, two-, three- and four-phase feeding) were compared, he performance of pigs was not influenced, but $\mathrm{N}$ excretion reduced with multi-phase feeding (Lee et al., 2000). In that experiment, daily $\mathrm{P}$ excretion was numerically lower in the multi-phase feeding programme than in the one-phase feeding programme, but the effect as not statistically significant, likely due to the confounding effect of faecal DM excretion. With assumptions about BW gain and feed:gain ratio for different phases, the effect of phase-feeding strategies can be estimated (Knowlton et al., 2004). For instance, when one-phase feeding with constant dietary $\mathrm{P}(0.50 \%$ of diet $)$ was compared with three-phase feeding with dietary $\mathrm{P}$ of $0.50,0.45$ and $0.40 \%$ of diet to achieve feed: gain of $0.42,0.34$ and 0.27 for pigs, of $20-50,50-80$ and $80-120 \mathrm{~kg}$ BW, $\mathrm{P}$ intake and subsequent excretion might be decreased by $12.5 \%$ (Knowlton et al., 2004).

Similar or even better improvements in the precision of $\mathrm{P}$ feeding can be achieved with poultry by using a four-phase feeding system. Several trials have evaluated and determined the $\mathrm{nPP}$ requirement of broilers in a four-phase feeding system (Angel et al., 2000; Ling et al., 2000). The replacement of average commercial usage with a four-phase feeding system can reduce dietary nPP by 5 , 15 and $40 \%$ in grower, finisher and withdrawal phases, respectively (Angel et al., 2000).

\section{Improving $P$ bioavailability}

The availability of $\mathrm{P}$ in feed is critical from a nutritional and environmental aspect, as 
offering less available $\mathrm{P}$ than required will impair animal production and health, and available $P$ in excess of requirement will result in increased excretion of $\mathrm{P}$ in a form that is most susceptible to runoff. In grains, a significant proportion of total $\mathrm{P}$ is present as phytate (Eeckhout and De Paepe, 1994; Ravindran et al., 1994; Steiner et al., 2007). Phytate $\mathrm{P}$ is not available to non-ruminants, as they lack the enzyme phytase required to degrade phytate to inorganic P. There has been a plethora of studies demonstrating the impact of improving $\mathrm{P}$ availability and reducing phytate $\mathrm{P}$ in feed ingredients commonly fed to non-ruminants.

Exogenous phytase has been used extensively in swine diets to improve dietary $\mathrm{P}$ bioavailability. In barrows, supplementation of 2500 and 12,500 U of Escherichia coli phytase $\mathrm{kg}^{-1}$ to a diet deficient in available P (0.15\% below NRC, 1998, recommendation) improved average daily gain (ADG) and increased the breaking strength and ash weight of the metacarpal bone as compared to a no-phytase diet estimated to be adequate in available $\mathrm{P}$ (Veum et al., 2006). When compared with a P-adequate diet, supplementation of 500 , 2500 and 12,500 U of E. coli phytase $\mathrm{kg}^{-1}$ diet increased $\mathrm{P}$ absorption and reduced $\mathrm{P}$ excretion by 35,42 and $61 \%$. The effect of phytase on production and $\mathrm{P}$ excretion has been observed at all phases of swine growth. The addition of phytase (500, 750 and 1000 $\mathrm{U} \mathrm{kg}^{-1}$ diet) to a diet calculated to be deficient in available $\mathrm{P}$ to nursery, growing and finishing pigs had no effect on ADG, feed efficiency and bone ash (Brana et al., 2006). Rather, phytase supplementation improved apparent P digestibility (by $22-44 \%$ of $\mathrm{P}$-adequate diet) and available $\mathrm{P}$ increased by $0.06-0.17 \mathrm{~g} \mathrm{U}^{-1}$ phytase consumed. There are similar studies that reported a reduction in $\mathrm{P}$ excretion by pigs with phytase supplementation to a low-P diet. Supplementation of phytase at 166, 333 and $500 \mathrm{U} \mathrm{kg}^{-1}$ of low-P diet reduced $\mathrm{P}$ excretion by 4,18 and $23 \%$ and 17,19 and $22 \%$ in grower and finisher phase, respectively, and phytase supplementation at $500 \mathrm{U} \mathrm{kg}^{-1}$ diet was equivalent to $0.87-0.96 \mathrm{~g}$ inorganic $\mathrm{P}$ from dicalcium phosphate (Harper et al.,
1997). In a similar study, phytase supplementation to a low-P diet resulted in reduced $\mathrm{P}$ excretion as compared to pigs fed a P-adequate diet, and phytase supplementation at $450 \mathrm{U} \mathrm{kg}^{-1}$ diet was equivalent to $0.2 \mathrm{~g}$ inorganic $\mathrm{P} \mathrm{kg} \mathrm{kg}^{-1}$ of maize-soybean meal-based finisher diet (Veum and Ellersieck, 2008).

As in pigs, the avian digestive tract lacks the phytase enzyme, so supplementation of poultry diets with exogenous phytase has been widely adopted to improve $\mathrm{P}$ availability. There are several reports of $\mathrm{P}$ excretion being reduced by $15-61 \%$ in broilers fed a diet supplemented with phytase (Simons et al., 1990; Żyła et al., 2001; Paik, 2003). Supplementation of a low $\mathrm{nPP}$ diet with phytase resulted in a $17-24 \%$ and $7-24 \%$ reduction in total $P$ excretion by broilers and turkeys, respectively, as compared to P-adequate diets (Maguire et al., 2004). Reduction of litter $P$ to a similar extent was reported by Leytem et al. (2008) and McGrath et al. (2010) when broiler diets were supplemented with phytase.

\subsection{Novel Feed Ingredients}

The development of genetically modified low-phytate grains (maize, soybeans) is another approach in improving $\mathrm{P}$ availability in feed for non-ruminants. Feeding lowphytate soybean increased apparent $\mathrm{P}$ digestibility in pigs as compared to pigs fed on regular soybeans (Powers et al., 2006). Excretion of total and water-soluble $\mathrm{P}$ decreased by 19 and $15 \%$ with low-phytate soybean meal and decreased further (by 27 and $18 \%$ ) with the addition of phytase to the low-phytate soybean diet. Similarly lowphytate barley also reduced $\mathrm{P}$ excretion by pigs (Htoo et al., 2007).

The effects of phytase and low-phytate grains appear to be additive. Faecal $\mathrm{P}$ excretion decreased by 12 and 15\% in pigs fed diets with low-phytate maize and lowphytate soybeans as compared to the pigs fed diets with regular maize and soybeans (Hill et al., 2009). In the same experiment, faecal $\mathrm{P}$ excretion decreased further in pigs fed a low-phytase diet supplemented with 
phytase as compared to pigs fed a diet with regular feed and no phytase.

The low-phytate feed approach is successful in the poultry industry as well. A transgenic variety of maize developed by the US Department of Agriculture (USDA) and named 'high available phosphate corn' (HAPC) is similar to its wild variety in total $\mathrm{P}$ concentration, but the $\mathrm{P}$ is six times more available than in its wild counterpart. Replacing normal yellow dent maize with HAPC in the diet of male broilers resulted in $8-23 \%$ reductions in $\mathrm{P}$ excretion, irrespective of age and dietary nPP (Yan et al., 2000). Likewise, $P$ excretion was 33 and $43 \%$ less in 1- to 10-day-old chicks fed low-phytate maize and barley-based diets as compared to chicks fed a wild-type grain-based diet without and with $\mathrm{P}$ supplementation, respectively (Jang et al., 2003).

The advancement of recombinant DNA technology has allowed researchers to produce transgenic plants capable of expressing microbial phytase in the endosperm of seeds, another means of providing microbial phytase to non-ruminants. The efficacy of a variety of maize expressing an E. coliderived phytase gene in maintaining performance and $\mathrm{P}$ digestion has been evaluated (Nyannor et al., 2007). Diets with the maize expressing the microbial phytase gene were equivalent to microbial phytase $\left(16,500 \mathrm{U} \mathrm{kg}^{-1}\right.$ diet$)$ in maintaining animal performance and in reducing faecal $\mathrm{P}$ excretion.

Another innovative approach of reducing $\mathrm{P}$ excretion in pigs is the development of phytase transgenic pigs, but this approach is expensive and controversial. Golovan et al. (2001) developed transgenic pigs expressing phytase and reported that true P digestibility was higher in transgenic weanling and growing-finishing pigs as compared to their non-transgenic counterparts (48 versus $88 \%$ and 52 versus $99 \%$, respectively). This resulted in a 75 and $56 \%$ lower concentration of $\mathrm{P}$ in faeces of weanling and growingfinishing transgenic pigs than in nontransgenic pigs. Due to controversy about the possibility of meat from genetically engineered pigs in the food system, support for this research programme was withdrawn and the last 'Enviropigs' were slaughtered in 2012 (Schimdt, 2012).

\subsection{Conclusion}

Animal agriculture always has been and still is considered one of the major contributors to water quality impairment. The intensification of livestock production has yielded great benefits in terms of food supply, but has aggravated the problem of $\mathrm{P}$ imbalance by concentrating manure. While several management strategies may be adopted, nutritional management strategies have been identified as the most powerful and economically viable solution. Further research is needed to refine the $\mathrm{P}$ requirements of livestock species and to improve dietary $\mathrm{P}$ availability. Continued progress will improve the efficacy of nutritional strategies, allowing continued increases in animal protein with reduced environmental loading of $\mathrm{P}$.

\section{References}

Angel, R., Applegate, T.J. and Christman, M. (2000) Effect of dietary non-phytate phosphorus (nPP) on performance and bone measurements in broilers fed on a four-phase feeding system. Poultry Science 79, 21-22.

Arriaga, H., Pinto, M., Calsamiglia, S. and Merino, P. (2009) Nutritional and management strategies on nitrogen and phosphorus use efficiency of lactating dairy cattle on commercial farms: an environmental perspective. Journal of Dairy Science 92, 204-215.

Brana, D.V., Ellis, M., Castaneda, E.O., Sands, J.S. and Baker, D.H. (2006) Effect of a novel phytase on growth performance, bone ash, and mineral digestibility in nursery and grower-finisher pigs. Journal of Animal Science 84, 1839-1849.

Bravo, D., Meschy, F., Bogaert, C. and Sauvant, D. (2002) Effects of fungal phytase addition, formaldehyde treatment and dietary concentrate content on ruminal phosphorus availability. Animal Feed Science and Technology 99, 73-95.

Bravo, D., Meschy, F., Bogaert, C. and Sauvant, D. (2003) Phosphorus availability of oilseed meals 
determined by the apparent faecal digestibility technique. Animal Feed Science and Technology 108, 43-60.

Brokman, A.M., Lehmkuhler, J.W. and Undersander, D.J. (2008) Reducing phosphorus inputs for grazing Holstein steers. Journal of Animal Science 86, 712-719.

Chebud, Y., Naja, G.M. and Rivero, R. (2011) Phosphorus run-off assessment in a watershed. Journal of Environmental Monitoring 13, 66-73.

Combs, N.R., Kornegay, E.T., Lindemann, M.D. and Notter, D.R. (1991) Calcium and phosphorus requirement of swine from weaning to market weight: I. Development of response curves for performance. Journal of Animal Science 69, 673-681.

Dhandu, A.S. and Angel, R. (2003) Broiler nonphytin phosphorus requirement in the finisher and withdrawal phases of a commercial four-phase feeding system. Poultry Science 82, 1257-1265.

Dou, Z., Ferguson, J.D., Fiorini, J., Toth, J.D., Alexander, S.M., et al. (2003) Phosphorus feeding levels and critical control points on dairy farms. Journal of Dairy Science 86, 3787-3795.

Eeckhout, W. and De Paepe, M. (1994) Total phosphorus, phytate-phosphorus and phytase activity in plant feedstuffs. Animal Feed Science and Technology 47, 19-29.

Ellenberger, H.G., Newlander, J.A. and Jones, C.H. (1950) Composition of the bodies of dairy cattle. Vermont Agriculture Experiment Station Bulletin 588, 1-66.

Erickson, G.E., Klopfenstein, T.J., Milton, C.T., Hanson, D. and Calkins, C. (1999) Effect of dietary phosphorus on finishing steer performance, bone status, and carcass maturity. Journal of Animal Science 77, 2832-2836.

Erickson, G.E., Klopfenstein, T.J., Milton, C.T., Brink, D., Orth, M.W., et al. (2002) Phosphorus requirement of finishing feedlot calves. Journal of Animal Science 80, 1690-1695.

Fisher, J.B., Olsen, R.L., Soster, F.M., Engle, B. and Smith, M. (2009) The history of poultry waste contamination in the Illinois River Watershed as determined from sediment cores collected from Tenkiller Ferry Reservoir (Oklahoma, United States). In: Proceedings of the 2009 International Symposium on Environmental Science and Technology, 2-5 June, Shanghai, China, pp. 1222-1238.

Gaskin, J.W., Risse, L.R., Faucette, L.B., Segars, W.I. and Worley, P.C. (2001) Beef cattle production impacts on water quality. In: Proceedings of the 2001 Georgia Water Resources Conference, 26-27 March, 2001,
University of Georgia, Athens, Georgia, pp. 416-419.

Geisert, B.G., Erickson, G.E., Klopfenstein, T.J., Macken, C.N., Luebbe, M.K., et al. (2010) Phosphorus requirement and excretion of finishing beef cattle fed different concentrations of phosphorus. Journal of Animal Science 88, 2393-2402.

Godoy, S. and Meschy, F. (2001) Utilisation of phytate phosphorus by rumen bacteria in a semi-continuous culture system (Rusitec) in lactating goats fed on different forage to concentrate ratios. Reproduction, Nutrition, Development 41, 259-265.

Golovan, S.P., Meidinger, R.G., Ajakaiye, A., Cottrill, M., Wiederkehr, M.Z., et al. (2001) Pigs expressing salivary phytase produce lowphosphorus manure. Nature Biotechnology 19, 741-745.

Harper, A.F., Kornegay, E.T. and Schell, T.C. (1997) Phytase supplementation of low-phosphorus growing-finishing pig diets improves performance, phosphorus digestibility, and bone mineralization and reduces phosphorus excretion. Journal of Animal Science 75, 31743186.

Harrison, J., Knowlton, K., James, B., Hanigan, M.D., Stallings, C. and Whitefield, E. (2012) Case Study: National survey of barriers related to precision phosphorus feeding. The Professional Animal Scientist 28, 564-568.

Hastad, C.W., Dritz, S.S., Tokach, M.D., Goodband, R.D., Nelssen, J.L., et al. (2004) Phosphorus requirements of growing-finishing pigs reared in a commercial environment. Journal of Animal Science 82, 2945-2952.

Havenstein, G.B., Ferket, P.R. and Qureshi, M.A. (2003) Growth, livability, and feed conversion of 1957 versus 2001 broilers when fed representative 1957 and 2001 broiler diets. Poultry Science 82, 1500-1508.

Hill, B.E., Sutton, A.L. and Richert, B.T. (2009) Effects of low-phytic acid corn, low-phytic acid soybean meal, and phytase on nutrient digestibility and excretion in growing pigs. Journal of Animal Science 87, 1518-1527.

Htoo, J.K., Sauer, W.C., Zhang, Y., Cervantes, M., Liao, S.F., et al. (2007) The effect of feeding lowphytate barley-soybean meal diets differing in protein content to growing pigs on the excretion of phosphorus and nitrogen. Journal of Animal Science 85, 700-705.

Huyghebaert, G., De Groote, G. and Keppens, L. (1980) The relative biological availability of phosphorus in feed phosphates for broilers. Annales de Zootechnie 29, 245-263. 
James, E., Kleinman, P., Veith, T., Stedman, R. and Sharpley, A. (2007) Phosphorus contributions from pastured dairy cattle to streams of the Cannonsville Watershed, New York. Journal of Soil and Water Conservation 62, 40-47.

Jang, D.A., Fadel, J.G., Klasing, K.C., Mireles, A.J. Jr, Ernst, R.A., et al. (2003) Evaluation of lowphytate corn and barley on broiler chick performance. Poultry Science 82, 1914-1924.

Jarrett, J.P., Hanigan, M.D., Ward, R., Sirois, P. and Knowlton, K.F. (2011) Total and inorganic phosphorus content of an array of feedstuffs. Journal of Dairy Science 94, 660.

Jarrett, J.P., Wilson, J.W., Ray, P.P. and Knowlton, K.F. (2014) The effects of forage particle length and exogenous phytase inclusion on phosphorus digestion and absorption in lactating cows. Journal of Dairy Science 97, 411-418.

Jongbloed, A.W. and Lenis, N.P. (1998) Environmental concerns about animal manure. Journal of Animal Science 76, 2641-2648.

Kebreab, E., Odongo, N.E., McBride, B.W., Hanigan, M.D. and France, J. (2008) Phosphorus utilization and environmental and economic implications of reducing phosphorus pollution from ontario dairy cows. Journal of Dairy Science 91, 241-246.

Kellogg, R.L., Lander, C.H., Moffitt, D.C. and Gollehon, N. (2000) Manure nutrients relative to the capacity of cropland and pastureland to assimilate nutrients: spatial and temporal trends for the United States. USDA/NRCS/ERS. Available at: www.nrcs.usda.gov/technical/land/ pubs/ manntr.pdf (accessed 6 January 2014).

Kertz, A.F. (1998) Variability in delivery of nutrients to lactating dairy cows. Journal of Dairy Science 81, 3075-3084.

Keshavarz, K. (2000) Reevaluation of non-phytate phosphorus requirement of growing pullets with and without phytase. Poultry Science 79, 11431153.

Ketaren, P.P., Batterham, E.S., White, E., Farrell, D.J. and Milthorpe, B.K. (1993) Phosphorus studies in pigs 1. Available phosphorus requirements of grower/finisher pigs. British Journal of Nutrition 70, 249-268.

Kincaid, R.L., Garikipati, D.K., Nennich, T.D. and Harrison, J.H. (2005) Effect of grain source and exogenous phytase on phosphorus digestibility in dairy cows. Journal of Dairy Science 88, 2893-2902.

Kleinman, P., Blunk, K.S., Bryant, R., Saporito, L., Beegle, D., et al. (2012) Managing manure for sustainable livestock production in the Chesapeake Bay Watershed. Journal of Soil and Water Conservation 67, 54A-61A.

Knowlton, K.F. and Herbein, J.H. (2002) Phosphorus partitioning during early lactation in dairy cows fed diets varying in phosphorus content. Journal of Dairy Science 85, 1227-1236.

Knowlton, K.F., Radcliffe, J.S., Novak, C.L. and Emmerson, D.A. (2004) Animal management to reduce phosphorus losses to the environment. Journal of Animal Science 82, E173-E195.

Knowlton, K.F., Taylor, M.S., Hill, S.R., Cobb, C. and Wilson, K.F. (2007) Manure nutrient excretion by lactating cows fed exogenous phytase and cellulase. Journal of Dairy Science 90, 43564360, doi:http://dx.doi.org/ 10.3168/jds.2006879 (accessed 10 September 2014).

Kornegay, E.T. and Verstegen, M.W.A. (2001) Swine nutrition and environmental pollution and odor control. In: Lewis, A.J. and Southern, L.L. (eds) Swine Nutrition. CRC Press, Boca Raton, Florida, pp. 609-630.

Lee, J.H., Kim, J.D., Kim, J.H., Jin, J. and Han, I.K. (2000) Effect of phase feeding on the growth performance, nutrient utilization and carcass characteristics in finishing pigs. Asian Australian Journal of Animal Science 13, 1137-1146.

Leytem, A.B., Widyaratne, G.P. and Thacker, P.A. (2008) Phosphorus utilization and characterization of ileal digesta and excreta from broiler chickens fed diets varying in cereal grain, phosphorus level, and phytase addition. Poultry Science 87, 2466-2476.

Ling, B., Angel, C.R., Applegate, T.J., Zimmermann, N.G. and Dhandu, A.S. (2000) The nonphytate requirement of broilers in a four phase feeding program. Poultry Science 79, 11.

Lopez, H., Kanitz, F.D., Moreira, V.R., Wiltbank M.C. and Satter, L.D. (2004) Effect of dietary phosphorus on performance of lactating dairy cows: milk production and cow health. Journal of Dairy Science 87, 139-145.

MacDonald, G.K., Bennett, E.M., Potter, P.A. and Ramankutty, N. (2011) Agronomic phosphorus imbalances across the world's croplands. Proceedings of the National Academy of Sciences 108, 3086-3091.

McGrath, J.M., Sims, J.T., Maguire, R.O., Saylor, W.W. and Angel, R. (2010) Modifying broiler diets with phytase and vitamin D metabolite (25$\mathrm{OH} \mathrm{D}(3)$ ): impact on phosphorus in litter, amended soils, and runoff. Journal of Environmental Quality 39, 324-332.

Maguire, R.O., Sims, J.T., Saylor, W.W., Turner, B.L., Angel, R., et al. (2004) Influence of phytase addition to poultry diets on phosphorus forms and solubility in litters and amended soils. Journal of Environmental Quality 33, 2306-2316.

Martín-Tereso, J., Gonzalez, A., Van Laar, H., Burbano, C., Pedrosa, M.M., et al. (2009) In situ ruminal degradation of phytic acid in 
formaldehyde-treated rice bran. Animal Feed Science and Technology 152, 286-297.

Martz, F.A., Belo, A.T., Weiss, M.F., Belyea, R.L. and Goff, J.P. (1990) True absorption of calcium and phosphorus from alfalfa and corn silage when fed to lactating cows. Journal of Dairy Science 73, 1288-1295.

Mjoun, K., Kalscheur, K.F., Hippen, A.R. and Schingoethe, D.J. (2008) Ruminal phosphorus disappearance from corn and soybean feedstuffs. Journal of Dairy Science 91, 39383946.

Nelson, N.O. and Mikkelsen, R.L. (2005) Balancing the phosphorus budget of a swine farm: a case study. Journal of Natural Resources and Life Sciences Education 34, 90-95.

NRC (National Research Council) (1978) Nutrient Requirements of Dairy Cattle, 5th revised edn. National Academies Press, Washington, DC.

NRC (1979) Nutrient Requirements of Swine, 8th revised edn. National Academies Press, Washington, DC.

NRC (1988) Nutrient Requirements of Swine, 9th revised edn. National Academies Press, Washington, DC.

NRC (1989) Nutrient Requirements of Dairy Cattle, 6 th revised edn. National Academies Press, Washington, DC.

NRC (1994) Nutrient Requirements of Poultry, 9th revised edn. National Academies Press, Washington, DC.

NRC (1996) Nutrient Requirements of Beef Cattle. 7th revised edn, National Academies Press, Washington, DC.

NRC (1998) Nutrient requirements of Swine, 10th revised edn. National Academies Press, Washington, DC.

NRC (2001) Nutrient Requirements of Dairy Cattle, 7th revised edn. National Academies Press, Washington, DC.

NRC (2012) Nutrient Requirements of Swine, 11th revised edn. National Academies Press, Washington, DC

Nyannor, E.K., Williams, P., Bedford, M.R. and Adeola, O. (2007) Corn expressing an Escherichia coli-derived phytase gene: a proofof-concept nutritional study in pigs. Journal of Animal Science 85, 1946-1952.

Odongo, N.E., McKnight, D., KoekKoek, A., Fisher, J.W., Sharpe, P., et al. (2007) Long-term effects of feeding diets without mineral phosphorus supplementation on the performance and phosphorus excretion in high-yielding dairy cows. Canadian Journal of Animal Science 87, 639-646.

Paik, I. (2003) Application of phytase, microbial or plant origin, to reduce phosphorus excretion in poultry production. Asian Australian Journal of Animal Science 16, 124-135.

Panda, A.K., Rama Rao, S.V., Raju, M.V.L.N. and Bhanja, S.K. (2005) Effects of dietary nonphytate phosphorus levels on egg production, shell quality and nutrient retention in white leghorn layers. Asian Australian Journal of Animal Science 18, 1171-1175.

Park, W.Y., Matsui, T., Konishi, C., Kim, S.W., Yano, F., et al. (1999) Formaldehyde treatment suppresses ruminal degradation of phytate in soybean meal and rapeseed meal. British Journal of Nutrition 81, 467-471.

Park, W.Y., Matsui, T., Yano, F. and Yano, H. (2000) Heat treatment of rapeseed meal increases phytate flow into the duodenum of sheep. Animal Feed Science and Technology 88, 31-37.

Pathak, H., Mohanty, S., Jain, N. and Bhatia, A. (2010) Nitrogen, phosphorus, and potassium budgets in Indian agriculture. Nutrient Cycling in Agroecosystems 86, 287-299.

Pote, D.H., Kingery, W.L., Aiken, G.E., Han, F.X., Moore, P.A. Jr, et al. (2003) Water-quality effects of incorporating poultry litter into perennial grassland soils. Journal of Environmental Quality 32, 2392-2398.

Poulsen, H.D., Jongbloed, A.W., Latimier, P. and Fernández, J.A. (1999) Phosphorus consumption, utilization and losses in pig production in France, The Netherlands and Denmark. Livestock Production Science 58, 251-259.

Powers, W.J., Fritz, E.R., Fehr, W. and Angel, R. (2006) Total and water-soluble phosphorus excretion from swine fed low-phytate soybeans. Journal of Animal Science 84, 1907-1915.

Ravindran, V., Ravindran, G. and Sivalogan, S. (1994) Total and phytate phosphorus contents of various foods and feedstuffs of plant origin. Food Chemistry 50, 133-136.

Ray, P.P., Jarrett, J. and Knowlton, K.F. (2013) Effect of dietary phytate on phosphorus digestibility in dairy cows. Journal of Dairy Science 96, 11561163.

Roberson, K.D. (2004) Estimation of the dietary calcium and non-phytate phosphorus needs of growing commercial tom turkeys weighing four to twelve kilograms. International Journal of Poultry Science 3, 175-178.

Ruan, Z., Zhang, Y.G., Yin, Y.L., Li, T.J., Huang, R.L., et al. (2007) Dietary requirement of true digestible phosphorus and total calcium for growing pigs. Asian Australian Journal of Animal Science 20, 1236-1242.

Satter, L.D., Klopfenstein, T.J. and Erickson, G.E. (2002) The role of nutrition in reducing nutrient output from ruminants. Journal of Animal Science 80, E143-E156. 
Schimdt, S. (2012) Genetically engineered pigs killed after funding ends. Postmedia News, June 22, 2012. Available at: http://www.canada.com/ technology/science/Genetically+engineered+pi gs+killed+after+funding+ends/6819844/story. $\mathrm{html}$ (accessed 6 January 2014).

Schindler, D.W. (1977) Evolution of phosphorus limitation in lakes: natural mechanisms compensate for deficiencies of nitrogen and carbon in eutrophied lakes. Science 195, 260-262.

Selle, P.H. and Ravindran, V. (2008) Phytatedegrading enzymes in pig nutrition. Livestock Science 113, 99-122.

Sharpley, A. (1999) Agricultural phosphorus, water quality, and poultry production: are they compatible? Poultry Science 78, 660-673.

Sharpley, A. and Tunney, H. (2000) Phosphorus research strategies to meet agricultural and environmental challenges of the 21st century. Journal of Environmental Quality 29, 176-181.

Shigaki, F., Sharpley, A. and Prochnow, L.I. (2006) Animal-based agriculture, phosphorus management and water quality in Brazil: options for the future. Scientia Agricola 63, 194-209.

Simons, P.C.M., Versteegh, H.A.J., Jongbloed, A.W., Kemme, P.A., Slump, P., et al. (1990) Improvement of phosphorus availability by microbial phytase in broilers and pigs. British Journal of Nutrition 64, 525-540.

Steiner, T., Mosenthin, R., Zimmermann, B., Greiner, R. and Roth, S. (2007) Distribution of phytase activity, total phosphorus and phytate phosphorus in legume seeds, cereals and cereal by-products as influenced by harvest year and cultivar. Animal Feed Science and Technology 133, 320-334.

Tamminga, S. (1992) Nutrition management of dairy cows as a contribution to pollution control. Journal of Dairy Science 75, 345-357.

Ternouth, J.H. (1990) Phosphorus and beef production in northern Australia. 3. Phosphorus in cattle - a review. Tropical Grasslands 24, 159-169.

Tillman, A.D., Brethour, J.R. and Hansard, S.L. (1959) Comparative procedures for measuring the phosphorus requirement of cattle. Journal of Animal Science 18, 249-255.

USDA (US Department of Agriculture) (2001) Confined Animal Production and Manure Nutrients. ERS/AIB-771, June 2001. Washington, DC.

USEPA (US Environmental Protection Agency) (1998) Environmental Impacts of Animal Feeding Operations. Washington, DC, US, Environmental Protection Agency, Office of Water, Standards and Applied Sciences Division. Available at: http://www.epa.gov/ostwater/guide/ feedlots/ envimpct.pdf (accessed 17 December 2013).

USEPA (2003) National pollutant discharge elimination system permit regulation and effluent limitations guidelines and standards for Concentrated Animal Feeding Operations (CAFOs). Federal Register 68, 7176-7274.

USEPA (2012) Case studies on the impact of Concentrated Animal Feed Operations (CAFOs) on ground water quality. EPA 600/R-12/052, September 2012. ORD, NRMRL, Ada, Oklahoma.

Valk, H. and Šebek, L.B.J. (1999) Influence of longterm feeding of limited amounts of phosphorus on dry matter intake, milk production, and body weight of dairy cows. Journal of Dairy Science 82, 2157-2163.

VandeHaar, M.J. and St-Pierre, N. (2006) Major advances in nutrition: relevance to the sustainability of the dairy industry. Journal of Dairy Science 89, 1280-1291.

Varley, P.F., Callan, J.J. and O'Doherty, J.V. (2010) Effect of phosphorus level and phytase inclusion on the performance, bone mineral concentration, apparent nutrient digestibility, and on mineral and nitrogen utilization in finisher pigs Irish Journal of Agricultural and Food Research 49, 141-152.

Veum, T.L. and Ellersieck, M.R. (2008) Effect of low doses of Aspergillus niger phytase on growth performance, bone strength, and nutrient absorption and excretion by growing and finishing swine fed corn-soybean meal diets deficient in available phosphorus and calcium. Journal of Animal Science 86, 858-870.

Veum, T.L., Bollinger, D.W., Buff, C.E. and Bedford, M.R. (2006) A genetically engineered Escherichia coli phytase improves nutrient utilization, growth performance, and bone strength of young swine fed diets deficient in available phosphorus. Journal of Animal Science 84, 1147-1158.

von Keyserlingk, M.A.G., Martin, N.P., Kebreab, E., Knowlton, K.F., Grant, R.J., et al. (2013) Invited review: Sustainability of the US dairy industry. Journal of Dairy Science 96, 5405-5425, doi:http://dx.doi.org/10.3168/jds.2012-6354 (accessed 10 September 2014).

Waibel, P.E., Nahorniak, N.A., Dziuk, H.E., Walser, M.M. and Olson, W.G. (1984) Bioavailability of phosphorus in commercial phosphate supplements for turkeys. Poultry Science 63, 730737.

Waldroup, P.W. (1999) Nutritional approaches to reducing phosphorus excretion by poultry. Poultry Science 78, 683-691. 
Waldroup, P.W., Kersey, J.H., Saleh, E.A., Fritts, C.A., Yan, F., et al. (2000) Non-phytate phosphorus requirement and phosphorus excretion of broiler chicks fed diets composed of normal or high available phosphate corn with and without microbial phytase. Poultry Science $79,1451-1459$.

Wang, F., Sims, J.T., Ma, L., Ma, W., Dou, Z., et al. (2011) The phosphorus footprint of China's food chain: implications for food security, natural resource management, and environmental quality. Journal of Environmental Quality 40, 1081-1089.

Wang, M., Hu, Y., Tan, Z., Tang, S., Sun, Z., et al. (2008) In situ ruminal phosphorus degradation of selected three classes of feedstuffs in goats. Livestock Science 117, 233-237.

Wu, Z., Satter, L.D. and Sojo, R. (2000) Milk production, reproductive performance, and fecal excretion of phosphorus by dairy cows fed three amounts of phosphorus. Journal of Dairy Science 83, 1028-1041.

Wu, Z., Satter, L.D., Blohowiak, A.J., Stauffacher, R.H. and Wilson, J.H. (2001) Milk production, estimated phosphorus excretion, and bone characteristics of dairy cows fed different amounts of phosphorus for two or three years. Journal of Dairy Science 84, 1738-1748.

Yan, F., Kersey, J.H., Fritts, C.A., Waldroup, P.W., Stilborn, H.L., et al. (2000) Evaluation of normal yellow dent corn and high available phosphorus corn in combination with reduced dietary phosphorus and phytase supplementation for broilers grown to market weights in litter pens. Poultry Science 79, 1282-1289.

Yan, F., Kersey, J.H. and Waldroup, P.W. (2001) Phosphorus requirements of broiler chicks three to six weeks of age as influenced by phytase supplementation. Poultry Science 80, 455-459.

Yanke, L.J., Bae, H.D., Selinger, L.B. and Cheng, K.J. (1998) Phytase activity of anaerobic ruminal bacteria. Microbiology 144, 1565-1573.

Żyła, K., Koreleski, J., Świątkiewicz, S., Ledoux, D.R. and Piironen, J. (2001) Influence of supplemental enzymes on the performance and phosphorus excretion of broilers fed wheatbased diets to 6 weeks of age. Animal Feed Science and Technology 89, 113-118. 